From the time of his first papers in 1879, Dr. Clarke added continuously to the knowledge of British birds, but he also found fresh material on ornithological excursions to Brabant, Slavonia and Hungary, the Pyrenees and the delta of the Rhone, Iceland and the Faroes, and identified collections from Jan Mayen, Franz Josef Land and Hudson's Bay, from the Philippines and the Antarctic voyage of the Scotia.

Most of Clarke's working life was spent in the service of the Royal Scottish Museum, Edinburgh, where he finally succeeded Dr. R. H. Traquair as keeper of the Natural History Department in 1906. $\mathrm{He}$ was responsible there for the modernizing and enlivening of the exhibits, and his all-round knowledge of the vertebrate groups set the high standard of mounting which characterizes the galleries of that Museum. In addition to the volumes already mentioned, he published jointly "A Handbook of Yorkshire Vertebrata" (1881), Bartholomew's “Zoogeographical Atlas" (1911), edited Colonel Wardlaw Ramsay's posthumous "Birds of Europe and North Africa" (1923), rewrote Saunders' "Manual of British Birds" (1927), and for many years edited the Annals of Scottish Natural History and its successor the Scottish Naturalist.

Dr. Clarke's work gained him many marks of recognition. He received the I.S.O. in 1920 ; the University of St. Andrews made him LL.D.; the British Ornithologists' Union chose him as the first recipient of the Godwin-Salvin Medal ; and he was an honorary member of the American Ornithologists' Union and of the Ornithological Societies of Vienna and Budapest.

Dr. Clarke was borm in 1853, he resigned his keepership in the Royal Scottish Museum in 1921, and after a long period of failing health he died on May 10 , in his eighty-sixth year. ${ }^{-H e}$ did a great deal to stimulate the study of animal life in Scotland, and there must be many who, like the writer, owe much of their interest in natural history to his enthusiasm and kindly encouragement.

JAMES RITCHIE.

\section{Dr. E. Goulding}

Dr. ERnest Goulding, who retired from the service of the Imperial Institute in 1935 when holding the post of vice-principal in the Plant and Animal Products Department of the Institute, died in London on February 15 in his sixty-eighth year. Born in 1870, the fourth son of the late William Purdham Goulding, of Finsbury Park, he was educated at Tollington Park College and at the School of the Pharmaceutical Society, Bloomsbury, which he entered as a Bell scholar. He graduated B.Sc. in the University of London in 1898, he took his D.Sc. (Lond.) degree in 1903, and was a fellow of the Institute of Chemistry, and also of the Chemical Society.

Goulding was intended for the profession of a pharmacist, but after his training at Bloomsbury and a period of research work at the School, in 1896 he joined as an assistant chemist the staff of the
Scientific and Technical Department of the Imperial Institute under the direction of Prof. (now Sir Wyndham) Dunstan. For some years, he was engaged on the general work of the developing activities of the Institute, but before long he began to specialize in the study of cotton and of the hard and soft long vegetable fibres, in relation to the development of the production of these materials in Empire countries. The work on cotton, carried out in association with F. W. Barwick, was an important factor in the establishment of the now flourishing cotton-growing industries in Uganda and other British countries, and the early investigations of the long fibres proved of great value when Goulding took over the secretaryship of the Imperial Institute Advisory Committeo on Vegetable Fibres which, with the assistance of the technical staff of the Institute, has done important work on these fibres, notably in the case of sisal. Goulding thus acquired an outstanding knowledge of vegetable fibres and wrote his "Cotton and other Vegetable Fibres" for the Imperial Institute series of handbooks. It was a great satisfaction to him that in 1936, after his retirement, he was invited to give the Mather Lecture of the Textile Institute, choosing as his subject "Textile Fibres of Vegetable Origin : Forty Years of Investigation at the Imperial Institute". It is mainly for his work on fibres that Goulding will be professionally remembered, but his long service in editing the Bulletin of the Imperial Institute must also be recorded.

As a research chemist, Goulding showed much ability, and he was fortunate in enjoying an early period of comparative freedom for such work before the development of technical investigation and administrative work absorbed his time. Jointly with Prof. Dunstan, he published between 1894 and 1901 a series of papers of which seven were concerned with derivatives of hydroxylamine. A study of the volatile oil of the bark of Cinnamomum pedatinervium formed his thesis for the D.Sc. (Lond.) and led to the publication of a number of joint papers on volatile oils prepared in collaboration with junior colleagues.

Goulding was a man of cheerful kindliness and modesty, combined with an unassuming firmness on matters of principle. He was active in Church work, being for many years vicar's warden and lay reader at St. Cuthbert's, Wood Green. He was much interested in Church music and also in Esperanto. He married twice : first, in 1905, Charlotte, daughter of the late William Larney of Finsbury Park, who died in 1907; and secondly, in 1908, Kathleen Irvine, elder daughter of the late Nathaniel Irvine Hawkes, of Crich, Derbyshire, who, with her son E. Irvine Goulding, survives him.

S. E. C.

\section{WE regret to announce the following deaths :}

Prof. J. J. Abel, For. Mem. R.S., formerly professor of pharmacology in Johns Hopkins University, on May 26, aged eighty-one years.

Mr. G. S. Ram, O.B.E., formerly senior electrical inspector in the Factory Department of the Home Office, on May 21. 